\title{
Accomplishing Education in Open Universities through the Agency of Digital Media
}

\section{Jean A. Saludadez*}

University of the Philippines Open University, the Philippines

\begin{abstract}
This paper attempts to explain why and how open universities accomplish their educational purposes. The research explores the use of the Agency Framework as a theoretical anchor for examining and explaining how education/learning is possible at a distance. The paper illustrates how digital media are agents that participate in the accomplishment of teaching and learning research online. The study employs the ventriloqual approach that involves a three-step process of: (1) collecting archived/recorded online interactions; (2) identifying markers through which digital media appear to recurrently and iteratively express themselves in the recorded interactions; and (3) understanding or hearing what the markers are made to say. Using this approach, the paper shows how digital media afford the creation of interactive activities in a graduate level research course in an open university, enabling students to go through designing and implementing research using both quantitative and qualitative methodologies. Surfacing the agentive roles of digital media staged at teacher-students interactions provides insights into why education can be accomplished at a distance.
\end{abstract}

Keywords: digital media, agency, ventriloqual approach

\section{Education at Open Universities}

The UNESCO states that one of the core missions and values of higher education is to:

\footnotetext{
*Corresponding author. Email: jsaludadez@ upou.edu.ph
}

\section{(cc) BY-NC-ND}

This work is licensed under a Creative Commons Attribution-NonCommercial-NoDerivs 3.0 Unported License.

ISSN 1858-3431 AAOU Journal 2015 Vol. 10, No. 2 pp 67-79 
provide opportunities (espace ouvert) for higher learning and for learning throughout life, giving to learners an optimal range of choice and a flexibility of entry and exit points within the system, as well as an opportunity for individual development and social mobility in order to educate for citizenship and for active participation in society, with a worldwide vision, for endogenous capacity-building... .

(http://www.unesco.org/education/educprog/wche/declaration _eng.htm)

Open universities are known for their provision of education at a distance. They are:

higher learning institutions that are primarily concerned with education at a distance, namely, education in which the systematic teaching and the communication between student and teacher or institutions take place mainly by a variety of media.

(Asian Association of Open Universities, http://aaou.ouhk.edu.hk/)

This paper illustrates through the Agency Framework that open universities are able to accomplish education through the agency of digital media in a qualitative study that explores its use in explaining how and why education is possible at a distance. The exploration challenges the adequacy of present scholarship in the distance education discourse to explain why and how open universities accomplish their purposes (Lachtem, 2007; Zawacki-Richter, Bäcker \& Vogt, 2009; Davies, Howell, \& Petrie, 2010). The impetus for the work is the belief that the developing scholarship in organizational communication on agency (Cooren, 2004, 2006, 2010, 2011; Cooren \& Taylor, 1997; Taylor \& Van Every, 2000, 2011) can provide a theoretical basis for examining and explaning this issue. Digital media are taken in the broadest sense, covering the technology — hardware and software, including networks - and content.

\section{The Agency Framework}

The agency framework attempts to explain 'how one can act from a 
distance' or 'teleact' (Cooren, 2006, p. 82). The framework 'views interactions as streams, flows, or processes' and assumes that the 'ultimate origin of what is happening in a given interaction' is not the participants and their actions/moves 'precisely because these participants are themselves moved or acted upon by specific reasons that they come to stage (or not) in their discussions' (Cooren, 2010, p. 78). Rather, it assumes that action is shared between human and non-human agents configured upstream and downstream in a chain of agency. Upstream agents refer to agents that animate (such as principles, values and policies) interlocutors and what the latter 'make present or represent in their interactions', while downstream agents refer to the signs that interlocutors produce "whether under the form of texts, gestures, kinesic expressions, and what they do or make interlocutors do' (ibid., p. 57).

Within the agency framework, communication is seen as "not only a matter of people speaking or writing to each other, but that other things are continuously inviting and expressing themselves in day-to-day interactions' (Cooren, 2011, p. 11). These other things are agents. Being an agent means being able to act or speak 'on behalf (or in the name) of principal'. In the narrative economy, principal refers to a collective entity like a group, organization or society. (Taylor \& Van Every, 2000, as cited by Cooren, 2006, pp. 82-83).The ventriloqual approach assumes that 'various forms of agency can be invoked or mobilized in a given interaction or dialogue' (Cooren, 2010, p. 75).

The approach involves:

1. recording interactions as they happen or collecting recorded interactions;

2. identifying markers through which a variety of figures appear to recurrently and iteratively express themselves in the interactions; and

3. understanding or hearing what the figures are made to say.

\section{Acquisition of Research Knowledge and Skills at a Distance}

The acquisition of research knowledge and skills involves mentorship (Winston \& Fields, 2003, p. 167) that may be helped or 
hindered by a 'digital form of learning' (Breuer \& Schreier, 2007, para. 39). In a series of studies conducted by the author from 2010 to 2012 (Saludadez, 2010, 2011, 2012 2013; Saludadez \& He, 2012), it was shown that it is possible to build research capability online as the required interaction (Winston \& Fields, 2003) between students and teachers afforded by web-based technology. In the work presented here, knowledge on building research capability online is advanced by illustrating how digital media afford the acquisition of research knowledge that resulted in accomplishing the educational objectives of a graduate-level research course.

To surface the agentive role of digital media, data were taken from the written reflections of students enrolled in a graduate-level research course in distance education conducted at the UPOU (University of the Philippines Open University) Myportal powered by Moodle from September to November 2013. Written reflections are assumed to record the interactions that happened in the online course and lend themselves to ventriloqual analysis. The online course was a 12 -week course with 13 students whose research background varied from having research experience to not having any such experience at all. It was divided into six modules: 'Research and the Agenda for Research in Distance Education (DE)'; 'Various Perspectives and Epistemological Lenses'; 'Quantitative Methodology'; 'Qualitative Methodology', 'Research Ethics in DE'; and 'Voices in the DE'. The course was intended to develop students' reading of research in distance education as well as designing and implementing research on their own practice using appropriate perspectives. Its ultimate goal is for students to be able to contribute to the body of knowledge on open learning and distance education by conducting research and evaluation studies.

The students engaged in two main activities: (1) participation in forums where conceptual understandings of research derived from their readings was discussed and where guidance was provided for them to be able to conduct two mini-studies - one employing the quantitative approach, the other the qualitative approach; and (2) designing and implementing the mini-studies. 


\section{Agentive Roles of Digital Media}

In the following analysis, the digital media performed two roles in building research capability: first, it enabled students to interact with the course mentor based on their individual needs, and with mentors beyond the confines of the virtual classroom; and, second, it afforded the carrying out of the education objectives of the research course.

\section{Mentoring}

The excerpts presented below register (in bold fonts) the agentive role of the online learning platform for mentoring based on the students' individual needs:

The discussion forum and faculty-in-charge's (FIC's) prompts also helped immensely and pointed me in the right direction. (Student $\mathrm{B}$ )

With the help of our FIC [help was done through the forums], I was guided and walked through on what questions to write [about], especially in my qualitative mini-paper. I did not know how, when and where to start. (Student F)

... the research I conducted for this course was different from any research I had previously done in my postgraduate years. The material was not only more difficult but the research itself developed into something surprisingly intensive, given the limited time and resources. Sometimes it was difficult, especially going through the process of understanding and making conclusions on a problem, getting confused on unfamiliar concepts or simply getting lost in the format. I often became frustrated and overwhelmed. Nonetheless, my facilitator/advisor was constantly there [present through the fora] to provide us with guidance and support, and to encourage us that it is possible to conduct a research [project] and through this process we will be able to learn how to conduct the different types of research. (Student J) 
The following excerpts illustrate (in bold fonts) the agentive role of the online learning platform for mentoring beyond the confines of the virtual classroom:

The first reading, the Davis et al. study provided insights on recent trends in DE research, but I still needed to familiarize myself with a lot of research terminologies. It took me a bit of a while to digest the readings, some of which required more than a couple [of] readings to digest. True to research, I had to search the Internet for related materials to fill the gaps in my knowledge on research and distance education research. (Student B)

I had to read the prescribed reference materials and still searched for additional references for further explanation and examples... . Crafting the research questions was quite difficult at the start since qualitative research allows design flexibility. It's unlike quantitative research where you can limit to the 'what' and 'why' questions. Later on, I was able to find more examples of qualitative research questions through [an] Internet search. Eventually, I was able to distinguish its peculiar context of trying to draw or elicit responses from participants that involve thoughts, opinions, feelings, and emotions. (Student L)

Utilizing the previous semester's materials on MOOC and the other related materials I found on the Web, including additional readings on quantitative methodology and how to go about it, I started to gain perspective on how to phrase my quantitative research question I need to ask, how to conduct the data processing and analysis, and the format or content of the quantitative report I have to prepare as a result of the study. (Student G)

\section{Fulfilling educational objectives}

Digital media afforded the carrying out of the education objectives, i.e. developing students who can read research in DE as well as design and implement research on their own practice using appropriate perspectives. 
In particular, such agentive roles were performed by websites in accomplishing the first objective above, as seen (in bold fonts) in the following excerpt:

The International Review on Research in Open and Distance Learning (IRRODL), the Turkish Online Journal of Distance Education (TOJDE), and the European Journal of Open, Distance and E-Learning (EURODEL) websites came up as a good source of materials for related research. (Student B)

Meanwhile, the agentive role was performed by online survey tools, emails and analytical software for accomplishing the second objective, i.e. to develop capability to design and implement research on their own practice using appropriate perspective, as shown (in bold fonts) in the following excerpts. First, there were examples which referred to the conduct of quantitative research:

In quantitative data collection, I had to make use of an instrument that will measure the variables in my study. Given the urgency of our assignment requirement, online survey tools (e.g. Google drive) is an effective tool for measuring, observing, or documenting quantitative data. The survey must contain specific questions and response choices that will help in measuring trends and relations. I was able to administer the survey by sending it to the participants through e-mail. (Student J)

But something new that I experienced in EDDE206 was the use of Google Forms to develop my survey and questionnaire. All the efforts that were done manually before can be simplified by Google but it will still take patience and perseverance to create a purposeful study. Despite some limitations of Google Forms, the power of the Internet enables one to disseminate the survey forms easily and acquire results automatically. (Student D)

Second, here are examples in the conduct of qualitative research: 
In my second paper, my classmates were cooperative and helpful in answering my open-ended questions. It was short notice again but nevertheless they were willing to help me out in my paper. We had a robust exchange of emails which is enough proof that I did not violate the research ethic principle on free informed consent. (Student F)

While I initially considered having an email exchange or chatting with them so that I could have a more personal interaction with them and probe deeper, due to the difficulties in coordinating schedules and the demands of other responsibilities on the part of the participants, I ended up using an online survey form where they could answer the open-ended question in a manner that did not have any limitations. I analysed the qualitative data I obtained using Weft QDA, which is a user-friendly, free, open-source software tool for analysing textual data. (Student $\mathrm{E}$ )

The agency of the whole course being conducted online can also be said to have led to the fulfillment of the educational objectives of the course, as suggested in the following reflections:

Going through the process of making actual quantitative and qualitative studies became crucial to my understanding and appreciation of both concepts. I realized that no matter how much one read up on the subject matter, one can appreciate the differences fully only when one actually conducts the research process. (Student E)

Going through the various research processes in both quantitative and qualitative methodologies has clarified certain concepts and procedures that I previously ignored in my research work, although the methods and processes sometimes differ when research is conducted outside the academic context. Nonetheless, it was an enlightening experience for me. (Student G) 
I learned in the past three months what I should have learned in four years (or eight if you count my undergraduate work). (Student I)

Although I have done quite a few quantitative researches in the past, this course allowed me to explore and learn further about research in distance education, and the difference between quantitative and qualitative research. (Student J)

Further, realizing the research course's ultimate goal of building research capability to be able to contribute to the body of knowledge on distance education can be anticipated, as can be gleaned from the conclusions of the students' reflections:

This is truly exciting for I feel like my mini-study could provide a glimpse of what can be discovered in the field of distance learning in the Philippines or it could simply be a small contribution to efforts in putting together generalizable concepts in the area of distance education. (Student I).

In the end, I look back and realized that having gone through the details of both quantitative and qualitative research, this will give me great confidence for myself - that I would be able [to] conduct these types of research. After this course, I have no doubt in [my] mind that I would be able to navigate the course for my capstone project to complete the requirements of my MDE degree. (Student $\mathrm{M}$ ).

The mini-studies we conducted were a great experience. It has enabled me to wrap my head around the knowledge and skills needed to conduct qualitative and quantitative research. (Student B)

After doing and writing my mini-researches in this course, I am almost ready for doing a full-blown research. I still have the jitters but I know I can do it. (Student C) 


\section{Discussion}

As mentioned earlier, open universities as institutions of higher learning fulfil their education mandate by systematic teaching and communication through a variety of media. The traditional way of thinking about the media views it only as a tool that facilitates the learning process - a passive view of digital media. This study takes an active view of digital media as an agent that makes a difference in the educational process.

Some people subscribe to technology as 'the driving force in delivering education to open distance learners' (to quote the comment of a reviewer of this paper), and expect it to fulfil certain purposes 'For instance ... a proper LMS should be able to encourage collaborative learning and achieve the learning outcomes of a particular course' (again to quote the comment by the same reviewer). However, this seems to take the normative rather than the active sense of the role of technology in learning. Turning to the literature, there appears to have been no theoretical explanation of how technology does the work.

Thus, this study attempts to illustrate that digital media - the technology and the content - are agents that make a difference in the teaching and learning process, specifically in mentoring and in fulfilling the educational objectives of individual courses as staged in the teacher-students interactions. As agents, the digital media may act back and refuse to be mobilized in accomplishing an educational objective. Instances of the anti-agent role could be the focus of another study.

\section{Conclusion}

Through exploring the Agency Framework, the agentive role of digital media in accomplishing education at a distance can be surfaced. Such an exploration may contribute to the explanation of why education is possible at a distance and provide support for the legitimacy of open universities as institution of higher learning. 


\section{References}

Breuer, F., \& Schreier, M. (2007). Issues in learning about and teaching qualitative research methods and methodology in the social sciences. Forum Qualitative Sozialforschung / Forum: Qualitative Social Research, 8(1), Art. 30. Retrieved from http://nbnresolving.de/urn:nbn:de:0114-fqs0701307

Cooren, F. (2011). Figures in tension in organizational communication. Paper presented at the 2011 Annual Conference of the International Communication Association. Boston, USA, 26-30 May.

Cooren, F. (2010). Action and agency in dialogue: Passion, incarnation and ventriloquism. Amsterdam: John Benjamins Publishing Company.

Cooren, F. (2006). The organizational world as a plenum of agencies. In F. Cooren, J. R. Taylor \& E. J. Van Every (Eds.), Communication as organizing: Empirical and theoretical explorations in the dynamic of text and conversation (pp. 81-100). Mahwah, NJ: Lawrence Erlbaum.

Cooren, F. (2004). Textual agency: How texts do things in organizational settings. Organization, 11, 373-393.

Cooren, F., \& Taylor, J.R. (1997). Organization as an effect of mediation: Redefining the link between organization and communication. Communication Theory, 7(3), 219-260.

Davies, R. S., Howell, S.L., \& Petrie, J. A. (2010). A review of trends in distance education scholarship at research universities in North America, 1998-2007. The International Review of Research in Open and Distance Learning, 11(3). Retrieved from http://www.irrodl.org/index.php/irrodl/article/view/876/1607

Lachtem, C. (2007). A framework for researching Asian open and distance learning. Distance Education, 28(2),133-147. 
Saludadez, J.A. (2010). Affordances of online resources/technology in teaching and learning qualitative research at a distance. Paper presented at the 24th Annual Conference of the Asian Association of Open Universities. Melia Hotel, Hanoi, Vietnam, 26-28 October.

Saludadez, J.A. (2011). The agency of technology in teaching research in distance education. Paper presented at the 25th Annual Conference of the Asian Association of Open Universities. Wawasan University, Penang, Malaysia, 27 September-1 October.

Saludadez, J. A. (2012). Digital media as agents in the accomplishment of open and distance learning. Proposal submitted to the Asian Association of Open Universities Staff Exchange Fellowship Programme.

Saludadez, J.A., \& He, Y. J. (2012). Agents in the accomplishment of open and distance learning by two open universities. Paper presented at the 26th Annual Conference of the Asian Association of Open Universities. Makuhari Messe, Chiba, Japan, 16-18 October 2012.

Saludadez, J. A. (2013). Acceptance of authority: Agents in the accomplishment of open and distance learning. Paper presented at the International Communication Association Annual Conference. London, UK, 17-21 June.

Taylor, J.R., \& Van Every, E. J. (2000). The emergent organization. Communication as site and surface. Mahwah, NJ: Lawrence Erlbaum Associates.

Taylor, J.R., \& Van Every, E.J. (2011). The situated organization: Case studies in the pragmatics of communication research. New York: Routledge.

Winston, B.E., \& Fields, D.L. (2003). Developing dissertation skills of doctoral students in an internet-based distance education curriculum: A case study. The American Journal of Distance Education, 17(3), 161-172. 
Zawacki-Richter, O., Bäcker E. M., \& Vogt, S. (2009). Review of distance education research (2000 to 2008): Analysis of research areas, methods, and authorship patterns. The International Review of Research in Open and Distance Learning, 10(6). Retrieved from

http://www.irrodl.org/index.php/irrodl/article/view/741/1461 